\title{
Crítica científica de "Investigação criminal genética - banco de perfis genéticos, fornecimento compulsório de amostra biológica e prazo de armazenamento de dados" - Apontamentos sobre a inconstitucionalidade da Lei 12.654/2012
}

Scientific criticism of "DNA criminal investigation DNA database, mandatory DNA collection and time limit for data retention" - Notes on the unconstitutionality of Law 12.654/2012

Rodrigo Grazinoli Garrido ${ }^{1}$

Universidade Federal do Rio de Janeiro - Rio de Janeiro/RJ

grazinoli.forense@gmail.com

http://lattes.cnpq.br/4027138006793482

https://orcid.org/0000-0002-6666-4008

Resumo: Esta crítica científica partiu do que foi proposto pelo artigo "Investigação criminal genética - banco de perfis genéticos, fornecimento compulsório de amostra biológica e prazo de armazenamento de dados", na busca de oferecer evidências doutrinárias e empíricas que permitissem ampliar o diálogo acadêmico sobre a implantação do Banco Nacional de Perfis Genético (BNPG). Para tanto, realizou-se pesquisa exploratória e qualitativa, desenvolvida a partir de documentação da doutrina, trabalhos empíricos, julgados e normas relacionadas ao banco brasileiro e congêneres estrangeiros. É possível reconhecer a possibilidade do uso de referenciais diversos do apresentado pelo artigo em comento e, assim, o alcance de conclusões contrárias no que se refere, especialmente à ofensa ao princípio nemo tenetur se detegere na aplicação da Lei 12.654/2012. Além disso, limitações importantes quando à relação entre a redução

1 Pós-Doutor em Genética pela UFRJ; Mestre e Doutor em Ciências pela UFRJ e UFRRJ, respectivamente; Jovem Cientista do Nosso Estado - FAPERJ; Professor Adjunto FND-UFRJ e do PPGD-UCP; Perito Criminal IPPGF-PCERJ. 
de taxas de crime e o incremento dos bancos de perfis genéticos precisam ser enfatizadas.

Palavras-Chave: Lei 12.654/2012; DNA forense; constitucionalidade.

ABSTRACT: This scientific criticism was based on what was proposed by the article "DNA criminal investigation - DNA database, mandatory DNA collection and time limit for data retention" - Notes on the unconstitutionality of Law 12.654/2012", in the search to offer doctrinal and empirical evidences that allowed to expand the academic dialogue on the implantation of the National Database of Genetic Profiles (BNPG). For that, we conducted exploratory and qualitative research, developed from documentation of doctrine, empirical work, judgments and rules related to the Brazilian and foreign databases. It is possible to recognize the possibility of using different references from the one presented by the article in question and, thus, the scope of contrary conclusions, particularly regarding the offense to the principle nemo tenetur is detegere in the application of Law 12,654 / 2012. Furthermore, important limitations in relation to the reduction of crime rates and the increase in DNA databases need to be emphasized.

KeYwoRDs: Law 12.654/2012; forensic DNA; constitutionality.

\section{INTRODUÇÃO}

O artigo "Investigação criminal genética - banco de perfis genéticos, fornecimento compulsório de amostra biológica e prazo de armazenamento de dados”, buscou lançar luz sobre tema atualíssimo no contexto da persecução penal brasileira: a implantação do Banco Nacional de Perfis Genéticos (BNPG).

O tema é tão importante que questionamentos sobre constitucionalidade da doação obrigatória de DNA para a composição do BNPG pelos condenados por crimes praticados, dolosamente, com violência de natureza grave contra pessoa, ou por qualquer dos crimes hediondos, na forma do art. 9-A da Lei 12.654/2012, já alcançou o STF. Por meio do Recurso Extraordinário $\mathrm{n}^{\circ} 973.837$, o assunto teve reconhecida sua repercussão geral.

Também a pesquisa científica sobre o tema deve buscar, necessariamente, ir além da persecução penal, alcançando os limites de nossa 
Constituição na luta por resguardar direitos individuais e coletivos. Nesse ponto, o artigo analisado apresentou significativo incremento após a rodada de avaliação, sobretudo alargando a revisão da literatura nacional e internacional em busca de apresentar as diferentes visões sobre o tema. Isto deve ser pontuado, pois demonstra o papel do processo de revisão, como momento indispensável não só para apontar problemas e, eventualmente, rejeitar o trabalho, mas para incrementar o diálogo acadêmico e atuar ativamente no estabelecimento de uma obra que irá contribuir com o desenvolvimento da área.

Contudo, o cerne da questão, a possível ofensa ao princípio nemo tenetur se detegere, ao se aplicar a Lei 12.654/2012, em especial seu art. $9^{\circ}$-A, ainda pode ser mais explorado. Além disso, faz-se necessário enfatizar as limitações da relação entre bancos de perfis genéticos e resolução de crimes e, por fim, apresentar normatizações do BNPG que passaram despercebidas pelo artigo. Assim, por meio de pesquisa exploratória e qualitativa, desenvolvida a partir de documentação indireta de fontes secundárias, como livros e artigos, e primárias, oriundas de leis, decretos e resoluções, buscou-se ampliar o diálogo acadêmico, na proposta de revelar algumas opiniões que buscam complementar a análise realizada pelo artigo.

\section{Possíveis reflexos do BNPG na Segurança Pública}

Talvez uma das características que melhor representa os nossos dias seja o medo do crime. Em uma complexa relação de causa e efeito, essa realidade tem influenciado o que nos é apresentado pela mídia; o nosso estilo de vida; a demanda por elaboração e aplicação de leis; e, de forma geral, nossa saúde. A segurança pública e privada passou a ser pano de fundo, virtualmente, de toda discussão (LEMES e GARRIDO, 2017, p. 218).

Dessa forma, não é de se estranhar que um dos pontos escolhidos pelo artigo para justificar o estabelecimento do BNPG sejam as estatísticas criminais e, mais especificamente, os índices de elucidação de crimes de homicídios.

Não há dúvida de que os bancos de perfis genético estabelecem uma nova forma de investigação, contribuindo para a resolução de crimes, 
sobretudo homicídios e estupros (GARRIDO e RODRIGUES, 2015, p. 96). $\mathrm{O}$ artigo reconhece que a constituição e utilização dos bancos de perfis genéticos para esse campo é coadjuvante. No entanto, estabelece que:

[...] o uso de informações e bancos de dados genéticos pode ser um importante agente de mudança no panorama de impunidade em se tratando de crimes violentos no Brasil [...]. A eficácia do sistema de banco de perfis genéticos no Brasil dependerá, basicamente, da sua alimentação com o maior número de perfis de DNA possível. (SUXBERGER e FURTADO, 2018, p. 817)

Esta relação direta entre a constituição do banco e a redução da criminalidade foi encontrada também na opinião de estudantes de Ensino Médio e Superior que responderam a inquérito realizado por Garrido e Winter (2017, p. 124). Contudo, tal percepção se perde, quando a mesma pergunta é feita para profissionais, especialmente para aqueles da área do Direito. Estes últimos parecem já ter percebido que a redução dos índices de criminalidade depende de ações muito mais complexas, não podendo se vincular exclusivamente aos resultados desses bancos. Na verdade, este tipo de argumento serve muito bem à mídia e à demanda por leis ainda mais gravosas (GARRIDO e WINTER, 2017, p. 124).

A forma de relacionar o BNPG com os níveis de criminalidade utilizada pelo artigo segue o mesmo tratamento que a mídia de massa dá ao tema, como observado por Garrido, Garrido e Winter (2018, p. 74). Além de enfatizar a relação direta entre a constituição dos bancos de perfis genéticos e a redução da criminalidade, a mídia enfatiza propostas de antecipação do risco e de aumento da punibilidade. Em continuação, a mídia ainda aproveita para transmitir uma representação fantasiosa, com certas abordagens cinematográficas, do trabalho do perito e da utilização do BNPG. Por fim, ao enfatizar tal agenda, a mídia a faz em detrimento de outra função importante do BNPG, seu uso na localização de paradeiro.

O tamanho do banco parece também não se relacionar diretamente à taxa de resolução de crimes. É claro que uma análise matemática simples permitiria reconhecer que em países como o Brasil, em que o banco de perfis genéticos com fins criminais ainda está sendo constituído, haverá um incremento inicial, pois qualquer resultado obtido desta relação será inédito. Contudo, naqueles países em que os bancos 
já estão bem estabelecidos, como UK, o desempenho do banco não está necessariamente relacionado ao seu tamanho (WALLACE, 2008, p. S29; SANTOS, MACHADO e SILVA, 2013, p. 7).

O perigo é que a ênfase nesta relação fortalece uma visão antecipatória de risco, e, por isso, necessariamente discriminatória, e o clamor, cada vez mais evidente, pelo rápido incrementado dos bancos. Para tanto, é comum a flexibilização das normas que determinam os grupos de doadores compulsórios ou daquelas que dizem respeito ao tempo de manutenção dos perfis no banco, ofendendo direitos fundamentais.

Diga-se de passagem, a lei brasileira não estabelece esse período de manutenção do perfil obtido compulsoriamente através dos dispositivos alterados da LEP pela Lei 12.654/2012. Além disso, vale ressaltar que o depósito e cruzamento de dados genéticos de condenados, mantidos no banco depois do cumprimento das penas, gerou, em 2008, a condenação do Reino Unido pela Corte Europeia de Direitos Humanos no caso S. and Marper vs. The United Kingdom (UK, 2008).

\section{A Falácia sobre a Coleta Indolor e a Cooperação Passiva DO INVESTIGADO}

No que se refere à coleta do material biológico, do ponto de vista técnico, há que se deixar claro que a obtenção de sangue, seja venoso, com uso de seringa e agulha, ou capilar, por meio de lanceta ou caneta usada na determinação de glicemia, está praticamente abolido dos laboratórios de DNA forense. Também não é rotineiro a obtenção de fragmento de unha para referência de vivos colhida por laboratórios forenses, como suscitado pelo artigo. Os fragmentos de unha até são utilizados como evidências questionadas nos casos de suspeita de o doador ter arranhado uma vítima. Atualmente, o uso do suabe oral, que busca células da mucosa da boca é o mais utilizado.

Por lógico, é possível acompanhar o artigo quando considera ser o suabe oral um método fisicamente indolor. Todavia, não é possível o mesmo reconhecimento para a punção venosa ou a lancetação dactilar, p.ex. Todavia, o mais complexo não é a determinação do nível de dor, mas o papel do doador nessas coletas e, assim, o nível da intervenção em seus corpos. 
Não parece possível assumir sem crítica a posição do artigo quanto à passividade do doador. Na verdade, nenhum método de obtenção de amostra biológica, dependente apenas da "cooperação passiva do doador". Exemplo desta posição foi dado por Nicolitt e Wehrs (2015, p. 144). Estes autores consideram mesmo a coleta de suabe oral uma intervenção corporal, pois há ingerência sobre o corpo vivo da pessoa humana e a afetação de direitos fundamentais. Para estes autores as intervenções podem ser: 1) consentidas e não consentidas; 2) invasivas e não invasivas.

$\mathrm{Na}$ verdade, se analisado de forma ampla, torna-se difícil fazer valer a demanda de uso de método indolor do art. $9^{\circ}$-A da lei 12.652/2012. Algumas perspectivas foram dadas pela Resolução $\mathrm{n}^{0} 3$ do Comitê Gestor do Banco Nacional de Perfis Genéticos, quando se estabeleceu que na recusa da doação o procedimento não deve ser realizado. Todavia, o artigo em crítica desconhece as resoluções do comitê gestor e estabelece que "se não quiser cooperar; neste caso, estará optando pela adoção de outro método pelo profissional que estiver cumprindo a decisão judicial” (SUXBERGER e FURTADO, 2018, p. 828).

Ademais, o artigo não faz menção ao Decreto ${ }^{0} 7.950 / 2013$, que institui o Banco Nacional de Perfis Genéticos e a Rede Integrada de Bancos de Perfis Genéticos e, assim, o Comitê Gestor da Rede Integrada de Bancos de Perfis Genéticos (RIBPG), o qual publica estas Resoluções.

$\mathrm{Na}$ verdade, a posição contrária ao artigo, de que deve haver restrições à coleta obrigatória, sem consentimento, mesmo que por meio de suabe oral, advém de dados empíricos. Em Garrido e Garrido (2013, p. 302), é possível observar que alguns doadores, recusavam-se a abrir a boca para a realização do procedimento de coleta da mucosa, preferindo doar sangue. Assim, não é tão simples reconhecer o que "dói” em uma pessoa, principalmente quando se relaciona a algumas partes do corpo que podem significar mais do que objetivamente podemos notar externamente.

Esse é o caso da boca. Alves (2012, p. 84) nos diz que a palavra boca está rotineiramente relacionada a situações ou expressões que se relacionam a mistério, desejo, sentimento, intenção, segredo. Esse autor continua, considerando que a boca é o lugar de satisfação não só das necessidades alimentares, mas sexuais, como entendido por Freud. Assim, para alguns, abrir a boca e permitir que se passe um suabe pode ser 
equiparada ao ato de apresentar a genitália. Além disso, há a vergonha em apresentar uma boca doente, o que certamente não seria incomum para uma população em que o acesso ao atendimento odontológico tem se restringido a situações de emergência e com serviços mutiladores (SPEZZIA, CARVALHEIRO e TRINDADE, 2015, p. 109).

Vale destacar também que mesmo que se estabeleça um processo de consentimento por parte do doador, este deve ser considerado com muita cautela, pois a situação policial parece infantilizar os doadores que, na maioria das vezes, são pessoas já fragilizadas tanto pela vida, quanto pela situação em que estão envolvidos. Também de forma empírica, constatou-se que muitos doadores de material biológico no Instituto de Pesquisa e Perícias em Genética Forense da Polícia Civil do Estado do Rio de Janeiro, sequer liam os termos e pouco compreendiam do mesmo. Consentiam, pois não viam outra saída (GARRIDO e GARRIDO, 2013, p. 303). Assim, quando são capazes de expressar autônoma e completamente sua decisão em doar, o ato de dispor do seu corpo nunca é passivo.

Assim, justificar que não há agressão ao princípio de nemo tenetur se detegere, "[...] quando o Estado obriga o investigado ou condenado a colaborar passivamente, simplesmente não resistindo ao ato legal de retirada da sua amostra biológica de maneira adequada e indolor (como no caso da coleta de unha ou sangue)" (SUXBERGER e FURTADO, 2018, p. 836), não parece ter sustentação tão simples.

\section{Identificação ou Produção de Prova: o uso do BNPG}

Também, não parece viável sustentar que o BNPG "se trata de mero procedimento de classificação do condenado para dar início ao cumprimento da pena" (SUXBERGER e FURTADO, 2018, p. 830), de modo que o uso do banco teria função meramente identificadora e não de produção de prova, não ofendendo o princípio da não autoincriminação.

O próprio artigo, em crítica, mostra o interesse probatório dos perfis genéticos, quando menciona em suas conclusões que:

Se a retenção da informação genética tiver como supedâneo a LEP (art. $\left.9^{\circ}-\mathrm{A}\right)$, o perfil genético do sentenciado deverá permanecer 
no banco de dados pelo prazo prescricional do crime pelo qual condenado (aplicação analógica do art. $7^{\circ}$-A da Lei de Identificação Criminal). Como forma de atender ao interesse público de proteção da coletividade contra a reincidência, em vez de se utilizar a pena em concreto como parâmetro para a fixação desse prazo, como é da tradição brasileira após o trânsito em julgado da sentença para a acusação, mais adequado se mostra usar o prazo prescricional pela pena em abstrato, como literalmente se dessume do referido art. $7^{\circ}$-A da Lei 12.037/2009. (SUXBERGER e FURTADO, 2018, p. 837)

De imediato, vale destacar as palavras de André Nicolitt e Carlos Wehrs, quando reconhecem que a nova lei introduziria "aparato científico probante, a nosso ver travestido de forma de identificação” (2014, p. 135). A mesma percepção tem Maria Elizabeth Queijo, reconhecendo que a utilização do banco de perfis genéticos tem a pretensão de comprovar autoria/participação em delito, sendo a finalidade "inegavelmente probatória" (2013, p. 14).

Tecnicamente, a lei 12.654/2012 coloca em pé de igualdade o método de identificação por DNA e métodos clássicos de identificação criminal, como fotografia e papiloscopia. Contudo, "[...] a prova genética, alcançou posição de destaque nas varas criminais e de família, tornando-se um recurso ‘irresistível e imperioso' e deixando de ser meio complementar de prova para fundamentar as decisões dos magistrados" (GARRIDO e RODRIGUES, 2015, p. 101).

Além disso, o poder de ferir a intimidade, a privacidade e de intervir no corpo do doador é, virtualmente, ilimitada, quando se fala em Biologia Molecular (CUNHA e SCHIOCCHET, 2018, p. 134). A perda da privacidade, por sua vez, parece estar entre as maiores preocupações de parcela da população portuguesa e brasileira, quando se fala em uso de seu material genético mantido em bancos de dados como fins criminais (MACHADO e SILVA, 2013, p. 134; GARRIDO e WINTER, 2017, p. 122).

Não há espaço para aprofundar aqui o assunto, mas é preciso ficar claro que na ausência de um banco universalizado para identificação civil, não é possível o uso de amostras colhidas de um brasileiro para se confirmar sua identidade, senão por comparação com amostras familiares. No que se refere ao "familial searching", não regulamentado no Brasil, haveria ainda implicações nitidamente inconstitucionais, pois 
o perfil coletado dos condenados poderia ser utilizado para identificar familiares e vice-versa, ultrapassando a pessoalidade da pena.

É claro que toda a discussão entre uso do DNA para a identificação ou para a produção de prova, isto é, para a comparação com como evidências de crime, acaba por retornar à problemática de o banco de perfis genéticos agredir às garantias do Pacto de São José da Costa Rica, no que se refere à não autoincriminação. Por outro lado, se houver o consentimento do doador, de forma livre de vícios e esclarecido, expressão real de sua autonomia, não há o que se falar em lesão à direitos fundamentais (GARRIDO e GARRIDO, 2013, p. 300). Essa deveria ser a forma de coleta no contexto da identificação criminal, na hipótese do inciso IV do art. $3^{\circ}$ da Lei 12.037/2009, podendo inclusive ser de interesse da defesa.

\section{Considerações Finais}

Dentro dos limites de uma crítica científica e considerando as questões observadas, relacionadas à coleta obrigatória do material biológico, a determinação do perfil genético e seu armazenamento em banco de dados que servirá necessariamente para a produção de prova, é forçoso concluir diversamente do artigo analisado.

Tal tecnologia aplicada à persecução penal fere direitos fundamentais, mormente o de não autoincriminação e de privacidade, consagrados internacionalmente e em nossa Constituição Federal de 1988. Ademais, afeta a presunção de inocência, e, em virtude da carência de termo certo para a exclusão do perfil coletado de forma compulsória, "assemelhando-se a uma espécie de pena privativa de direitos de caráter perpétuo que não respeita o princípio da individualização da pena" (TAVARES, GARRIDO e SANTORO, 2016 p. 216-217).

Reconhece-se de toda forma, o papel da pesquisa para o desenvolvimento do tema e como forma de estimular outros ensaios inéditos sobre o assunto, seria interessante aproveitar a oportunidade para deixar uma série de questões que merecem aprofundamento, tais como: as limitações econômicas para a implantação BNPG; as relações entre as instituições de perícia oficial, administração penitenciária e justiça no que tange a gestão do BNPG; análises empíricas sobre os sujeitos doadores de material genético; possibilidade de uso do banco para pesquisa familiar; contradições existentes 
entre os atores que gerenciam o comitê gestor e a Rede Integrada de Bancos de Perfis Genéticos; os interesses de grandes corporações fornecedoras de reagentes e equipamentos para as análises genéticas e seus papeis nas decisões sobre o BNPG; controle de qualidade dos laboratórios vinculados ao Banco Nacional de Perfis Genéticos e a cadeia de custódia da prova.

\section{REFERÊNCIAS}

ALVES, E.G.R. Alguns Conhecimentos da Psicologia Necessários para o Cirurgião-Dentista, e Outros profissionais da Saúde. In: NIGRI, A.L. (Org) A Odontologia à Luz do Direito. Ed. Rubio. p. 77-102, 2012.

CUNHA, A.S.; SCHIOCCHET, T. Bancos de Perfis Genéticos para Fins de Persecução Criminal: Implicações Jurídicas à Privacidade, Intimidade e Estigmatização Genéticas. In: SCHIOCCHET, T.; GARRIDO, R.G. (Org). Bancos de Perfis Genéticos para Fins de Persecução Criminal: Práticas Periciais e Impactos Jurídico-Sociais (I). Multifoco, p. 127-154, 2018.

GARRIDO, R. G.; GARRIDO, F.de S.R.G. Consentimento informado em genética forense. Acta bioeth., v. 19, n. 2, p. 299-306, 2013. http://dx.doi.org/10.4067/ S1726-569X2013000200015

GARRIDO, R.G.; RODRIGUES, E. L. O Banco de Perfis Genéticos Brasileiro Três Anos após a Lei no 12.654. Revista de Bioetica y Derecho, v. 35, p. 94-107, 2015. http://dx.doi.org/10.1344/rbd2015.35.14284

GARRIDO, R.G., GARRIDO, F. de S.R.G.; WINTER, BC. de A. O Banco Nacional de Perfis Genéticos na Mídia de Massa. In: SCHIOCCHET, T. e GARRIDO, R.G. (Org). Bancos de Perfis Genéticos para Fins de Persecução Criminal: ensaios sobre o Direito Brasileiro (II). Multifoco, p. 69-86, 2018.

LEMES, M. A.; GARRIDO, R. G. Transformações das Instituições de Segurança Pública Brasileiras e seus Reflexos no Reconhecimento do Mandato e na Accountability. Direito \& Paz, v. 36, p. 217-233, 2017. Disponível em: <http://www.revista. unisal.br/lo/index.php/direitoepaz/article/view/604>. Acesso em: 06 mai. 2018. MACHADO, H. e SILVA, S. "Would you Accept Having your DNA Profile Inserted in the National Forensic DNA Database? Why?” Results of a Questionnaire Applied in Portugal", Forensic Science International: Genetics, 8(1), p.132-136, 2013. https://doi.org/10.1016/j.fsigen.2013.08.014

NICOLITT, A.; WEHRS, C. R. Intervenções corporais no Processo Penal e a nova identificação criminal. Lei 12.654/2012. Rio de Janeiro: Elsevier, 2014. 
QUEIJO, M. E. O princípio nemo tenetur se detegere e a coleta de material genético: identificação criminal ou colaboração na produção da prova? Boletim IBCCRIM, n. 250 , p. 13-15, set. 2013.

SANTOS, F.; MACHADO, H.; SILVA, S. Forensic DNA databases in European countries: Is size linked to performance? Life Sciences, Society and Policy. 2013. https://doi.org/10.1186/2195-7819-9-12

SPEZZIA, S.; CARVALHEIRO, E.M.; TRINDADE, L.deL. Uma análise das políticas públicas voltadas para os serviços de saúde bucal no Brasil. Rev. Bras. Odontol., v. 72, n. 1-2, p. 109-113. 2015. Disponível em: <http://revista.aborj.org.br/index. php/rbo/article/viewFile/603/468>. Aceso em: 06 mai. 2018.

TAVARES, N. L. F.; GARRIDO, R.G.; SANTORO, A. E. R. O Banco de Perfis Genéticos e a Estigmatização Perpétua: uma Análise do art. $9^{\circ}$-A da Lei 7.210/84 à Luz da Criminologia Crítica. Revista Jurídica (FIC), v. 4, p. 207-226, 2016.

UK. Case of S. and Marper V. The United Kingdom. 2008. Disponível em: <http:// www.legislation.gov.uk/ukpga/2012/9/contents/enacted>. Acesso em: 3 jun. 2014.

WALLACE, H. The UK National DNA Database: Balancing crime detection, human rights and privacy. EMBO Rep. 7 (Spec No): S26-S30, 2006. https://doi. org/10.1038/sj.embor.7400727.

WINTER, B.C. de A.; GARRIDO, R.G. Privacidade à Toda Prova: percepções de Brasileiros Sobre o Banco Nacional de Perfis Genéticos. Revista Duc In Altum Cadernos de Direito. vol. 9, no 17, p. 115-127, 2017. http://dx.doi.org/10.22293/ 2179-507x.v9i17.467

\section{Informações adicionais e declarações dos autores (integridade científica)}

Agradecimentos (acknowledgement): À FAPERJ, pela bolsa JCNE e ao Prof. Dr. Antonio Eduardo Ramires Santoro, pelas discussões valorosas sobre o tema.

Declaração de conflito de interesses (conflict of interest declaration): o autor confirma que não há conflitos de interesse na realização das pesquisas expostas e na redação deste artigo. 
Declaração de autoria e especificação das contribuições (declaration of authorship): todas e somente as pessoas que atendem os requisitos de autoria deste artigo estão listadas como autores; todos os coautores se responsabilizam integralmente por este trabalho em sua totalidade.

Declaração de ineditismo e originalidade (declaration of originality): $\mathrm{o}$ autor assegura que o texto aqui publicado não foi divulgado anteriormente em outro meio e que futura republicação somente se realizará com a indicação expressa da referência desta publicação original; também atesta que não há plágio de terceiros ou autoplágio.

Dados do processo editorial - crítica científica

(http://www.ibraspp.com.br/revista/index.php/RBDPP/about/editorialPolicies)

- Recebido em: 06/05/2018

Equipe editorial envolvida

- Controle preliminar e verificação de plágio: 09/05/2018

- Editor-chefe: 1 (VGV)

- Retorno rodada de correções: 10/05/2018

- Decisão editorial final: 20/05/2018

\section{COMO CITAR ESTA CRÍTICA CIENTÍFICA:}

GARRIDO, Rodrigo Grazinoli. Crítica científica de "Investigação criminal genética banco de perfis genéticos, fornecimento compulsório de amostra biológica e prazo de armazenamento de dados" - Apontamentos sobre a inconstitucionalidade da Lei 12.654/2012. Revista Brasileira de Direito Processual Penal, Porto Alegre, vol. 4, n. 2 , p. 889-900, mai./ago. 2018. https://doi.org/10.22197/rbdpp.v4i2.163

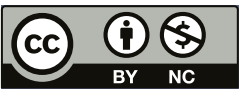

Esta obra está licenciada com uma Licença Creative Commons Atribuição-NãoComercial 4.0 Internacional. 